\title{
CRYPTOCOCCAL MENINGITIS IN HIV NEGATIVE PREGNANT WOMEN: CASE REPORT AND REVIEW OF LITERATURE
}

\author{
Maria Laura Botelho COSTA, João Paulo Dias de SOUZA, Antônio Francisco de OLIVEIRA NETO \& João Luiz PINTO E SILVA
}

\begin{abstract}
SUMMARY
Introduction: Cryptococcosis has become an important entity due to the epidemic of AIDS and therefore it is a significant opportunistic infection. However, there are case reports of cryptococcal meningitis in immune competent pregnant women. Since pregnancy is considered a period of relative immunosuppression, which likely prevents fetal rejection, this could explain the occurrence of opportunistic infections. Objective: To report a case of cryptococcosis, and review all cases involving pregnancy and neurocryptococcal infection in immune competent pregnant patients. Methods: Case report and systematic review of the literature using the MEDLINE and SciELO databases. Discussion: A total of 27 patients were analyzed from 19 studies. The mean age at diagnosis was 26.4 years. There were six patients in their first trimester of pregnancy, 10 in the second, eight in the third and three post-partum. The most prevalent symptoms were headache (85.2\%), altered vision $(44.4 \%)$, altered mental status $(44.4 \%)$, nausea (40.7\%) and fever $(33.3 \%)$. There were nine deaths $(33.3 \%)$. Most of the patients received intravenous amphotericin B as treatment $(77.8 \%)$. The majority $(66.6 \%)$ of the patients accomplished a term delivery with healthy infants. Conclusion: Cryptococcal meningitis should be considered during pregnancy in cases of unexplained headache, altered vision, altered mental status, nausea and fever. Patients with a confirmed diagnosis should be admitted and treated with amphotericin B.
\end{abstract}

KEYWORDS: Cryptococcal meningitis; Cryptococcosis; Pregnancy; Antifungal therapy.

\section{INTRODUCTION}

Cryptococcosis has been recognized as a clinical entity for over 110 years, since the discovery of Cryptococcus neoformans by SANFELICE ${ }^{25}$. Its occurrence was historically characterized as sporadic and generally associated with diseases that lead to cellular immune deficiency, such as leukemia, Hodgkin's disease, diabetes and systemic lupus ${ }^{16}$. However, due to the epidemic nature of acquired immunodeficiency syndrome (AIDS) cryptococcosis has become a major opportunistic infection accounting for morbidity and mortality in AIDS patients.

Two species within the genus Cryptococcus: C. neoformans (serotypes A, D, and hybrid $\mathrm{AD}$ ) and $C$. gattii (serotypes $\mathrm{B}$ and $\mathrm{C}$ ) are recognized to cause life-threatening disease ${ }^{16}$. The infection caused by Cryptococcus neoformans species complex has universal distribution, occurs in immune compromised individuals, and in urban environments rich in bird's feces. The infection caused by Cryptococcus gatti is considered prevalent in tropical and subtropical regions, affecting immune competent individuals from the rural areas, where the fungus is found in trees, particularly Eucalyptus spp. ${ }^{18}$.

In Brazil, cryptococcosis caused by $C$. neoformans occurs in all regions, however, C. gattii behaves as a primary pathogen and infects mostly native immunocompetent hosts (specially children and young people) in the North and Northeast (NE) regions of the country. The Southern macro region shows sporadic infections by this agent ${ }^{30}$.

Cryptococcus is a yeast fungus that most frequently infects the central nervous system (CNS) through hematogenous spread after inhalation into the lungs. Headaches and mild temperature elevation appear at the onset of CNS involvement, but other symptoms similar to those of an intracranial lesion or meningitis may arise subsequently ${ }^{26}$. The diagnosis of cryptococcal meningitis is often difficult. The headache, in the frontal and temporal regions, is intermittent at onset, but becomes continuous and progressively severe. Visual disturbances like diplopia and photophobia are also early symptoms. Other ocular disorders include neuroretinitis, retinal hemorrhages, strabismus, nystagmus, anisocoria, ptosis, retinal exudates, optic nerve atrophy and ophthalmoplegia. Papilledema is present in half of active cases, due to increased spinal fluid pressure ${ }^{17}$.

The initial site of infection in the lungs usually heals by encapsulation, leaving no recognizable tissue damage or just a nodule called cryptococcoma. However, a pneumonic form of cryptococcosis can occur and symptoms may include cough, chest pain, fever, weight 



Inst. Med. trop. S. Paulo, 51(5): 289-294, 2009.

loss and sputum production. Other forms of cryptococcal disease, such as cutaneous, visceral or bone disease are rare and prompt evaluation of cerebrospinal fluid even if no meningeal signs are present ${ }^{26}$.

Lumbar puncture in infected individuals reveals a spinal fluid clear, rarely turbid or xanthochromic in its appearance, depending on the stage or severity of the disease. Elevated pressures (up to $700 \mathrm{mmH}_{2} \mathrm{O}$ ) and protein counts as well as decreased glucose are other spinal findings ${ }^{17}$. The fungus can be visualized in cerebrospinal fluid with India ink mounts, where typical halo cells are seen ${ }^{8}$.

The aspect of the pathologic lesion is either mucoid or granulomatous, depending on the degree of cellular reaction. The fungus can be visualized in tissue by use of mucicarmine stain $^{8}$.

Pregnancy represents a vulnerable time for both mother and fetus, and is considered a period of relative immune suppression. During pregnancy, the mother's immunological status is down regulated in part to prevent fetal rejection due to paternally-derived histocompatibility antigens ${ }^{3}$.

There is still no clear evidence that pregnancy is a predisposing factor for cryptococcosis, however, the alteration of maternal T-cell activity, natural killer cells, polymorphonuclear leukocytes, macrophages, and specific antibodies may play an important role in the development of this disease ${ }^{10}$.

During pregnancy, the trophoblast does not express the classical major histocompatibility complex (MHC) class Ia or II molecules that are needed to present antigenic peptides to cytotoxic and T-helper (Th) cells, respectively. Instead, human leukocyte antigen (HLA)-G, a nonclassical MHC Ib molecule, is expressed. HLA-G may be a ligand for the natural killer cell receptor, therefore protecting the fetus from natural killer cell damage; activating suppressive CD8+ T cells, and influencing the organism's response towards an infection ${ }^{13}$.

Another important aspect to consider during pregnancy is the use of antifungal agents and the possible toxicities to the fetus. Treatment with amphotericin B for central nervous system (CNS) cryptococcosis during pregnancy has been suggested since 1958, and is usually considered the first therapeutic option with reported favorable maternal and fetal outcomes. This agent has a Food and Drug Administration (FDA) category $\mathrm{B}$ rating for use in pregnancy, with manageable toxicities of anemia, hypokalemia, and renal dysfunction for both mother and fetus ${ }^{10}$. No data is available to determine the optimal duration of antifungal therapy for cryptococcosis during pregnancy. However, nonpregnant patients without AIDS are treated with amphotericin B with or without flucytosine for 4-6 weeks based on clinical trial data ${ }^{2,9}$. After delivery, a change from amphotericin B to fluconazole has been postulated, to avoid amphotericin B's toxicity to the post-partum patient ${ }^{10}$. The use of antifungal agents during lactation is still unsettled and not recommended, with limited studies to support its safety.

Cryptococcosis in pregnancy, specially the neurologic presentation, represents a challenging clinical entity, as regards to the differential diagnosis it imposes and the remaining knowledge gaps on treatment and patient safety aspects. We faced one of these cases and to better understand cryptococcosis in pregnancy, we systematically reviewed all published cases involving pregnancy and neurocryptococcal infection in apparently immunocompetent patients without human immunodeficiency virus (HIV) infection. We were interested in identifying the symptoms present at the time of diagnosis, the maternal-fetal morbidity and mortality, and the type of treatment. In addition, we also report the case that motivated this systematic review.

\section{METHODS}

Search methods for identification of studies: The search of reports of cryptococcal meningitis cases diagnosed during pregnancy was carried out in the scientific literature covering a wide range of journals through MEDLINE and SciELO. These databases were investigated using the following search strategy: ("cryptococcal" or "Cryptococcus" or "cryptococcosis" or "neurocryptococcosis" or "torulosis") and ("pregnancy" or "maternal" or "gestational").

All reports of mycology proven cases of cryptococcal meningitis diagnosed during pregnancy were analyzed.

\section{RESULTS}

Case Report: A 37 year-old white Brazilian woman, 14 weeks pregnant, with a background of arterial hypertension, using methyldopa, was admitted due to altered mental status and dyslalia. The symptoms progressed with right-sided paresis, nausea, vomiting and divergent strabismus. Following the initial clinical assessment, computerized tomography scan and magnetic resonance imaging of her brain were obtained, with normal findings. The patient was subsequently transferred to the intensive care unit of the State University of Campinas Women's hospital (CAISM/UNICAMP), for observation and further examination.

Hepatic and renal functions, electrolytes, and serology for hepatitis, syphilis and HIV were negative. Blood cultures were also negative. A lumbar puncture was performed and revealed an opening pressure of $850 \mathrm{~mm} \mathrm{H} \mathrm{H}_{2}$, suggesting increased intracranial pressure (ICP). The cerebrospinal fluid analysis (CSF analysis) revealed a pleocytosis [red blood cells - $210 \mathrm{~mm}^{3}$ and leukocytes $272 \mathrm{~mm}^{3}$ (neutrophils 70\%; lymphocytes $27 \%$; eosinophils $2 \%$; monocytes $1 \%$ )], a reduced glucose level $(16 \mathrm{mg} / \mathrm{dL})$, and an elevated protein level $(95 \mathrm{mg} / \mathrm{dL})$. The diagnosis of cryptococcal meningitis was confirmed by the identification of the Cryptococcus neoformans isolated in CSF culture $\left(53 \mathrm{cells} / \mathrm{mm}^{3}\right)$.

Treatment with intravenous amphotericin B (monotherapy) was given with a total dose of $1500 \mathrm{mg}$ (daily dosage of $50 \mathrm{mg}$ during 30 days) and lumbar punctures were performed daily to monitor intracranial pressure, with liquoric drainage $(10-20 \mathrm{~mL})$ whenever a pressure over $250 \mathrm{mmHg}$ was noted. The patient responded to therapy with regression of symptoms and within five days of treatment, the ICP kept lower than $180 \mathrm{mmH}_{2} \mathrm{O}$. During this recovery period, laboratory tests showed maintained renal and hepatic functions but low levels of potassium that required intravenous repletion. Thirty days after admission, the patient was discharged to complete treatment with oral fluconazol $(750 \mathrm{mg} / \mathrm{day})$. The patient was examined every two weeks at the hospital's specialized prenatal care unit with adequate fetal growth. She required a beta-blocker for blood pressure control and daily oral solution of potassium for repletion. After sixteen weeks of oral fluconazol, a new lumbar puncture was performed and culture was negative for Cryptococcus spp. The medication was then gradually discontinued. 


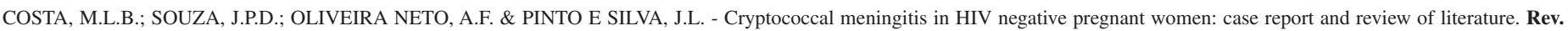
Inst. Med. trop. S. Paulo, 51(5): 289-294, 2009.

At 38 weeks of pregnancy, the patient was hospitalized in labor. Hours later, an emergency Cesarean-section was performed due to fetal distress. A healthy newborn was delivered. The newborn was adequate for gestational age, weighing 3095g with an Apgar score of 9/10 .

\section{REVIEW OF LITERATURE}

The electronic search resulted in the identification of 26 mycology proven cases of cryptococcal meningitis diagnosed during pregnancy in HIV negative women, from which 23 have already been reported in a review by ELY et al. (1998). Characteristics of the 26 cases and the present case are listed in Table 1.

The mean age of patients at diagnosis was 26.4 years-old. There were six patients in their first trimester of pregnancy, 10 in the second trimester, eight in the third trimester and three in post-partum period. The most prevalent symptoms were headache $(85.2 \%)$ followed by altered vision $(44.4 \%)$, including photophobia, blurred vision, diplopia, strabismus and papilledema. Altered mental status accounted for $44.4 \%$ of the symptoms, including: poor memory, dizziness, neck stiffness, somnolence, convulsions and coma. Nausea and vomiting were reported in $40.7 \%$ of the patients and fever in $33.3 \%$.

Nine of these 27 patients (33.3\%) died (cases 1, 2, 3, 8, 9, 10,11, 13 and 26). Eight deaths occurred in reports that preceeded the year 1975. $5 / 27(18.5 \%)$ patients that died had no adequate systemic treatment for cryptococcosis (cases 1, 8, 10, 11 and 26), and/or only confirmed diagnosis after autopsy.

Most of the patients analyzed (21/27) received intravenous amphotericin B as their antifungal therapy (77.8\%), with doses ranging from 600 to $7200 \mathrm{mg}$. Five of these 27 cases (18.5\%) were treated with complementary intrathecal amphotericin B (cases 6,7,12,17,21). Other antifungal drugs were described, such as flucytosine (cases 17, 22 and 24), oral fluconazole (cases 23 and 27) and itraconazole (case 20).

In regards to fetal and maternal outcomes, there were four cases of fetal death (14.8\%). One of them due to the mother's request of pregnancy termination at 24 weeks (case 18), and one due to miscarriage (3.7\%). Unfortunately seven cases $(25.9 \%)$ did not provide information about fetal outcomes and another four $(14.8 \%)$ did not provide any additional information other than if a successful pregnancy and delivery occurred. Despite the suboptimal information in some reports, it was clear that the majority of patients achieved a term or close to term delivery with healthy infants lacking overt signs of cryptococcal disease at time of birth or during follow-up (cases of up to four years of follow-up). There were two women with pre-eclampsia (cases 8 and 24).

\section{DISCUSSION}

Cryptococcosis is an important opportunistic disease in patients with AIDS or those undergoing immunosuppressive therapy. Cryptococcal meningitis is the most frequent clinical presentation. During pregnancy, the disease is rare and its course and possible complications have not been completely understood. Most studies suggest that the clinical features, course and outcome of cryptococcal meningitis are not influenced by pregnancy ${ }^{5}$.
However, pregnancy is considered a time of relative immunosuppression, which could in theory create a predisposition for opportunistic fungal infections, such as cryptococcosis ${ }^{10}$. For this reason, the diagnosis of cryptococcosis should be considered and pursued in pregnant patients presenting with altered vision, severe headache, altered mental status, seizures, nausea and unexplained fever.

Defining a population of pregnant patient at increased risk is a difficult task, since the pathological agents, Cryptococcus neoformans and Cryptococcus gattii, can be found in both, urban and rural areas, on house dust, in decomposed plants and in bird and bat feces ${ }^{22}$.

The case reported here and the review of 26 other cases from the literature shows impressive positive outcomes in patients correctly diagnosed and treated. The best results have been seen after 1975, with better intensive care practices and the use of amphotericin B. Fetal malformations have not been reported in these cases.

The recommendation for a patient with suggestive symptoms of cryptococcosis should include a detailed medical history, physical exam, blood, urine, sputum cultures for acid fast bacilli and fungi, lumbar puncture, serum cryptococcal antigen and histopathology analysis.

Once a diagnosis is established, amphotericin B with or without flucytosine is recommended. Careful monitoring for toxicities should be instituted, with daily renal function, electrolytes and complete blood count exams, to manage possible adverse effects such as anemia, hypokalemia and renal dysfunction. After delivery, the switch to oral fluconazole (400 to $800 \mathrm{mg}$ /day), a class C FDA medication, should be considered and breast feeding avoided ${ }^{10}$.

No data is available to ascertain the optimal duration of antifungal therapy for cryptococcosis during pregnancy, but non-pregnant immunocompetent women are treated for 4-6 weeks, based on controlled trials. A possible management of the disease in pregnancy is to individualize treatment and monitor each patient's clinical response, using serial laboratorial and imaging exams ${ }^{10}$.

There are no documented cases of fetal infection in immunocompetent patients with cryptococcosis. Only two cases of placental cryptococcosis have been reported, both in severely immunocompromised women, one of them with lupus ${ }^{20}$ and the other with AIDS ${ }^{19}$. However, none had newborns with demonstrable infection. There are three reported cases of possible vertical transmission, all of them in mothers co-infected with HIV ${ }^{4}$.

\section{CONCLUSION}

Cryptococcosis is one the most important fungal infections in Brazil with numerous case reports and region particularities. There has been an effort to answer doubts and to define a consensus for diagnosis, management and treatment of the disease with a guideline published in 2008 as a technical report ${ }^{28}$.

However, cryptococcal meningitis is rarely diagnosed during pregnancy, but it should be regarded as a possible entity in cases of unexplained headache, altered vision, altered mental status, nausea and fever. Pregnant patients with a confirmed diagnosis should be admitted and treated with amphotericin B. 


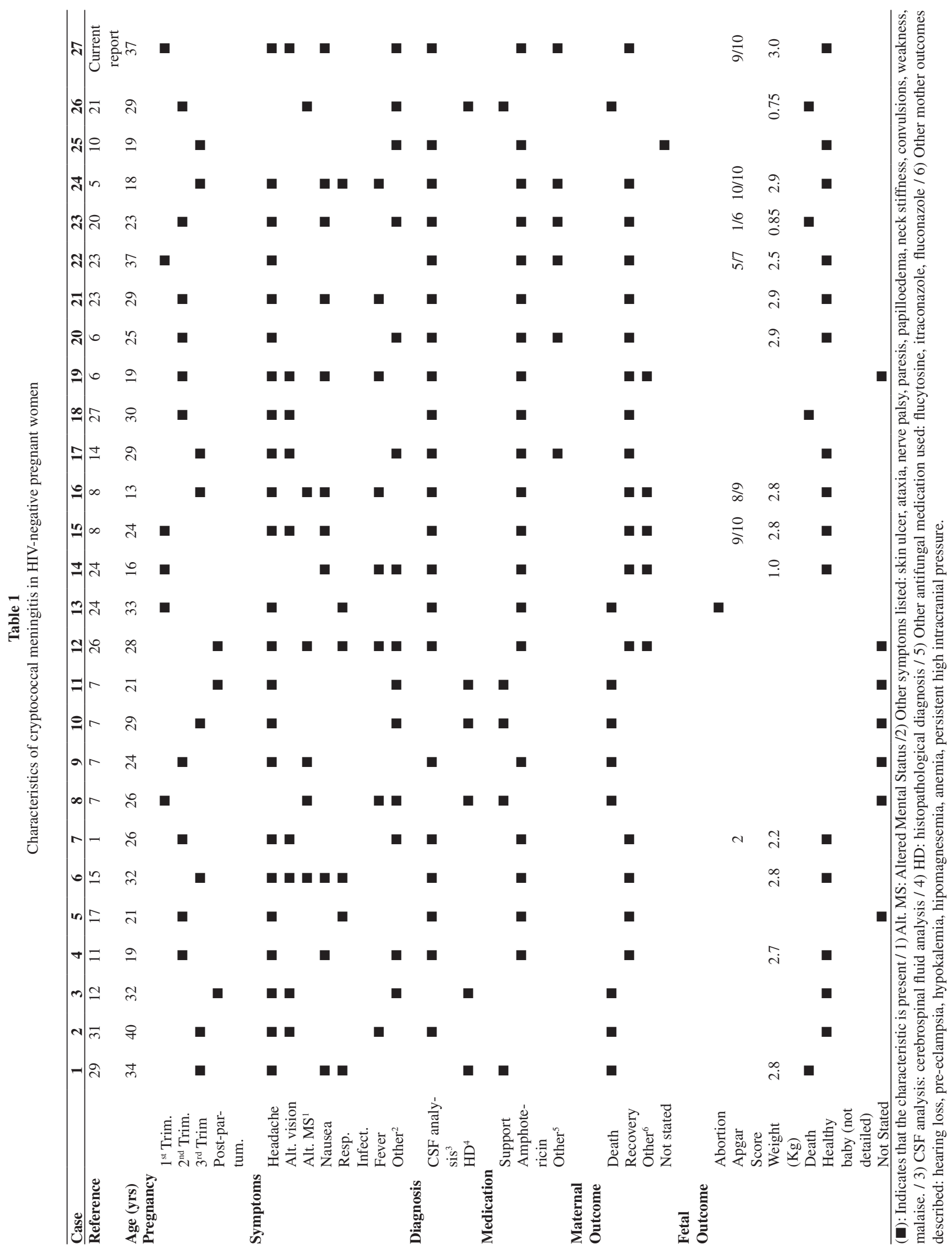


COSTA, M.L.B.; SOUZA, J.P.D.; OLIVEIRA NETO, A.F. \& PINTO E SILVA, J.L. - Cryptococcal meningitis in HIV negative pregnant women: case report and review of literature. Rev. Inst. Med. trop. S. Paulo, 51(5): 289-294, 2009.

New studies and case reports are needed to assure the safety and effectiveness of treatment with newer antifungal agents.

\section{RESUMO}

\section{Meningite criptocóccica em gestante HIV negativa: relato de caso e revisão da literatura}

Introdução: Com a epidemia da AIDS, a neurocriptococose foi melhor estudada e considerada infecção fúngica oportunista. No entanto, há casos descritos de gestantes acometidas, apesar de imunocompetentes. A gestação, por si só, pode ser considerada um período de imunossupressão, para adaptação materno-fetal, o que poderia predispor à instalação de certas infecções. Objetivos: Relato de caso de gestante com neurocriptococose e revisão sistemática dos casos descritos na literatura desta patologia durante a gestação, em pacientes imunocompetentes. Metodologia: Revisão sistemática com busca MEDLINE e SciELO. Resultados: Foram analisadas 27 pacientes com diagnóstico de neurocriptococse na gestação. A média de idade foi 26,4 anos. Seis pacientes estavam no primeiro trimestre de gravidez ao diagnóstico, 10 no segundo, oito no terceiro e três eram puérperas. O sintoma mais prevalente foi cefaléia $(85,2 \%)$, seguido por alteração visual $(44,4 \%)$, confusão mental $(44,4 \%)$, náusea $(40,7 \%)$ e febre $(33 \%)$. Houve nove óbitos maternos $(33,3 \%)$. Vinte e uma pacientes foram tratadas com anfotericina B $(77,8 \%)$. A maioria dos casos evoluiu com gestação a termo, com recém-nascidos saudáveis $(66,6 \%)$. Conclusões: Neurocriptococose deve ser um diagnóstico a se considerar na gestação, nos casos de cefaléia, alteração visual, confusão mental, náusea e febre persistentes, sendo indicada terapia intensiva e uso de anfotericina B.

\section{REFERENCES}

1. AITKEN, G.W. \& SYMONDS, E.M. - Cryptococcal meningitis in pregnancy treated with amphotericin B: a case report. J. Obstet. Gynaecol. Brit. Emp., 69: 677-679, 1962.

2. BENNETT, J.E.; DISMUKES, W.E.; DUMA, R.J. et al. - A comparison of amphotericin $\mathrm{B}$ alone and combined with flucytosine in the treatment of cryptococcal meningitis. New Engl. J. Med., 301: 126-131, 1979.

3. CATANZARO, A. - Pulmonary mycosis in pregnant women. Chest, 86 (suppl.): S14-S18, 1984.

4. CASTRO, G.; CERVI, M.C. \& MARTINEZ, R. - Vertical transmission of Cryptococcus neoformans from a mother coinfected with immunodeficiency virus. Case report. Rev. Soc. bras. Med. trop., 39: 501-503, 2006.

5. CHEN, C.P. \& WANG, K.G. - Cryptococcal meningitis in pregnancy. Amer. J. Perinatol., 13: 35-36, 1996

6. CHOTMONGKOL, V. \& SIRICHAROENSANG, S. - Cryptococcal meningitis in pregnancy: a case report. J. Med. Assoc. Thai., 74: 421-422, 1991.

7. CROTTY, J.M. - Systemic mycotic infections in northern territory aborigines. Med. J. Aust., 1: 184-186, 1965.

8. CUROLE, D.N. - Cryptococcal meningitis in pregnancy. J. Reprod. Med., 26: 317 319,1981

9. DISMUKES, W.E.; CLOUD, G.; GALLIS, H.A. et al. - Treatment of cryptococcal meningitis with combination amphotericin B and flucytosine for four as compared with six weeks. New Engl. J. Med., 317: 334-341, 1987.
10. ELY, E.W.; PEACOCK, J.E.; HAPONIK, E.F. \& WASHBURN, R.G. - Cryptococca pneumonia complicating pregnancy. Medicine (Baltimore), 77: 153-167, 1998

11. FELDMAN, C.R. - Cryptococcosis (Torulosis) of the central nervous system treated with amphotericin B during pregnancy. Sth. med. J. (Bgham. Ala.), 52: 1415-1417, 1959

12. GANTZ, J.A.; NUETZEL, J.A. \& KELLER, L.B. - Cryptococcal meningitis treated with amphotericin B. AMA Arch. intern. Med., 102: 795-800, 1958

13. IWATANI, Y.; AMINO, N.; TACHI, J. et al. - Changes of lymphocyte subsets in normal pregnant and postpartum women: postpartum increase of NK/K (Leu7) cells. Amer. J. Reprod. Immunol. Microbiol., 18: 52-55, 1988.

14. JONES, J.M. \& GRAIG, W.A. - Cryptococcal meningitis: resolution eight months after antifungal therapy. Sth. med. J. (Bgham. Ala.), 76: 1567-1569, 1983.

15. KUO, D. - A case of torulosis of the central nervous system during pregnancy. Med. J. Aust., 49: 558-560, 1962.

16. KWON-CHUNG, K.J.; SORRELL, T.C.; DROMER, F.; FUNG, E. \& LEVITZ, S.M. - Cryptococcosis: clinical and biological aspects. Med. Mycol., 38: 205-213, 2000

17. LiTTMAN, M.L. - Cryptococcosis (Torulosis) current concepts and therapy. Amer. J. Med., 27: 976-998, 1959.

18. LOPES, J.O.; COSTA, J.M.; STREHER, L.A. et al. - Criptococose não associada à AIDS no Rio Grande do Sul: relato de oito casos e revisão da literatura SulRiograndense. Rev. Soc. bras. Med. trop., 30: 369-372, 1997.

19. MASATOSHI, K.; ABRAMOWSKY, C.R. \& SANTOSCOY, C. - Cryptococcosis of the placenta in a women with acquired immunodeficiency syndrome. Hum. Path., 20: 920-921, 1989.

20. MOLNAR-NADASDY, G.; HAESLY, I.; REED, J. \& ALTSHULER, G. - Placental cryptococcus in a mother with systemic lupus erythematosus. Arch. Path. Lab. Med., 118: 757-759, 1994.

21. NUCCI, A.; MACIEL, J.A.; QUEIROZ, L.S.; MONTENEGRO, M.A. \& CARVALHO, R.B. - Pseudocystic form of neurocryptococcosis in pregnancy. Case report. Arq. Neuropsiquiatr., 57: 678-682, 1999.

22. PAPPALARDO, M.C.S.M. \& MELHEM, M.S.C. - Cryptococcosis: a review of the Brazilian experience for the disease. Rev. Inst. Med. trop. S. Paulo, 45: 299-305, 2003

23. PEREIRA, C.A.P.; FISCHMAN, O.; COLOMBO, A.L.; MORON, A.F. \& PIGNATARI, A.C.C. - Neurocriptococose durante a gravidez. Revisão de literatura. Revisão de dois casos. Rev. Inst. Med. trop. S. Paulo, 35: 367-371, 1993.

24. PHILPOT, C.R. \& LO, D. - Cryptococcal meningitis in pregnancy. Med. J. Aust., 2: $1005-1007,1972$

25. SANFELICE,F. - Contributo alla morfologia e biologia dei blastomiceti che si sviluppano nei succhi di alcuni frutti. Ann. Ig. R. Univ. Roma, 4: 463-498, 1894.

26. SILBERFARB, P.M.; SAROSI, G.A. \& TOSH, F.E. - Cryptococcosis and pregnancy Amer. J. Obstet. Gynecol., 112: 714-720, 1972

27. STAFFORD, C.R.; FISHER, J.F.; FADEL, H.E. et al. - Cryptococcal meningitis in pregnancy. Obstet. Gynecol., 62(suppl. 3): 35-37, 1983.

28. TECHNICAL REPORT - Guidelines in cryptococcosis-2008. Rev. Soc. bras. Med. trop., 41: 524-544, 2008

29. TIMERMAN, H.J. - Fatal case of yeast meningitis in pregnancy. Chicago, Gynecology Society, 1935 
COSTA, M.L.B.; SOUZA, J.P.D.; OLIVEIRA NETO, A.F. \& PINTO E SILVA, J.L. - Cryptococcal meningitis in HIV negative pregnant women: case report and review of literature. Rev. Inst. Med. trop. S. Paulo, 51(5): 289-294, 2009.

30. TRILLES, L.; LAZÉRA, M.S.; WANKE, B. et al. - Regional pattern of the molecular types of Cryptococcus neoformans and Cryptococcus gattii in Brazil. Mem. Inst. Oswaldo Cruz, 103: 455-462, 2008
31. WAGER, H.E. - Torula uveitis. Trans. Amer. Acad. Ophtalmol. Otolaryngol., 58: 61-67, 1954

Received: 30 July 2008

Accepted: 30 July 2009 